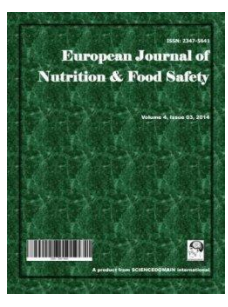

European Journal of Nutrition \& Food Safety

6(3): 148-168, 2016, Article no.EJNFS.2016.018

ISSN: 2347-5641

SCIENCEDOMAIN international

www.sciencedomain.org

\title{
Country Differences in the History of Use of Health Claims and Symbols
}

\author{
Sophie Hieke $^{1^{*}}$, Nera Kuljanic ${ }^{1}$, Laura Fernandez ${ }^{1}$, Liisa Lähteenmäki ${ }^{2}$, \\ Violeta Stancu ${ }^{2}$, Monique M. Raats ${ }^{3}$, Bernadette Egan ${ }^{3}$, Kerry Brown $^{3}$, \\ Hans Van Trijp ${ }^{4}$, Ellen Van Kleef ${ }^{4}$, Erica Van Herpen ${ }^{4}$, Andrea Gröppel-Klein ${ }^{5}$, \\ Stephanie Leick ${ }^{5}$, Katja Pfeifer ${ }^{5}$, Wim Verbeke ${ }^{6}$, Christine Hoefkens $^{6}$, \\ Sinne Smed ${ }^{7}$, Léon Jansen ${ }^{8}$, Anita Laser-Reuterswärd ${ }^{9}$, Živa Korošec ${ }^{10}$, \\ Igor Pravst ${ }^{10,11}$, Anita Kušar ${ }^{10,11}$, Marija Klopčič ${ }^{11}$, Jure Pohar ${ }^{11}$, \\ Azucena Gracia ${ }^{12}$, Tiziana de Magistris ${ }^{12}$ and Klaus G. Grunert ${ }^{2}$ \\ ${ }^{1}$ European Food Information Council, Sablon Tower, Rue Joseph Stevens 7, 1000 Brussels, Belgium. \\ ${ }^{2}$ MAPP Centre, Aarhus University, Bartholins Allé 10, 8000 Aarhus C, Denmark. \\ ${ }^{3}$ Food, Consumer Behaviour and Health Research Centre, University of Surrey, Guildford, Surrey, \\ GU27XH, United Kingdom. \\ ${ }^{4}$ Marketing and Consumer Behaviour Group, Wageningen University, Hollandseweg 1, 6706 KN \\ Wageningen, The Netherlands. \\ ${ }^{5}$ University Saarland, 66123 Saarbrücken, Germany. \\ ${ }^{6}$ Department of Agricultural Economics, Ghent University, 9000 Gent, Belgium. \\ ${ }^{7}$ University of Copenhagen, Nørregade 10, 1165 København, Denmark. \\ ${ }^{8}$ Schuttelaar and Partners, Zeestraat 84, 2518 AD, Den Haag, The Netherlands. \\ ${ }^{9}$ This Work was Carried Out when Anita Was Still Working at the Swedish National Food Agency, \\ Livsmedelsverket, Box 622, SE-751 26 Uppsala, Sweden. \\ ${ }^{10}$ Nutrition Institute, Tržaška Cesta 40, 1000 Ljubljana, Slovenia. \\ ${ }^{11}$ University of Ljubljana, Biotechnical University, Groblje 3, 1230 Domžale, Slovenia. \\ ${ }^{12}$ Agrifood Research and Technology Centre of Aragon, Avda. Montañana 930, 50059 Zaragoza,
} Spain.

Authors' contributions

The work was led by author SH. All authors were involved in the interviews. All authors have read and approved the final manuscript.

Article Information

DOI:10.9734/EJNFS/2016/20758

Received $7^{\text {th }}$ August 2015

Accepted $28^{\text {th }}$ July 2016

Original Research Article

Published $13^{\text {th }}$ August 2016

\section{ABSTRACT}

Health-related claims and symbols are intended as aids to help consumers make informed and healthier food choices but they can also stimulate the food industry to develop food that goes hand

*Corresponding author: Email: sophie.hieke@eufic.org; 
in hand with a healthier lifestyle. In order to better understand the role that health claims and symbols currently have and in the future potentially can have, the objective of the CLYMBOL project ("Role of health-related claims and symbols in consumer behaviour", Grant no 311963) is to investigate consumers' understanding of health claims and symbols, and how they affect purchasing and consumption [1].

As part of this endeavour, it is important to understand the history of use of claims and symbols in Europe. What have consumers been exposed to and how were these health-related messages used and discussed among the public? In this study, we interviewed key stakeholders across Europe about how health claims have been regulated in their country, how health symbols have been and currently are being treated, what form of monitoring there is or should be and how both health claims and symbols have been debated in the public opinion. In 26 European Union (EU) Member States, opinions from 53 key informants from up to three different stakeholder groups were gathered: national food authorities, representatives of the food industry, and consumer organisations.

While 14 Member States reported (at least partial) regulation of the use of health claims and/or symbols before the introduction of the EU Regulation (EC 1924/2006) on nutrition and health claims made on foods [2], mandatory reporting of use had only been in place in three EU Member States. A number of voluntary codes of practice for health claims and/or symbols (i.e. pre-approval or justification when challenged) was said to be in use in 15 Member States. There are only a few national databases on health claims and symbols available, the data for which is often incomplete. Only eight Member States reported having some form of database from which information about health claims and symbols could be extracted. The stakeholders interviewed expressed a strong interest in measuring the impact of health claims and symbols, particularly research into the effects on consumer behaviour (e.g. awareness and understanding, attitudes towards products carrying claims and symbols and purchase/consumption effects), public health (health outcomes and changes in national health status due to the introduction of claims and symbols on food products) and economic aspects including sales, return on investment and reputation measurements. Public debates were said to have evolved around the topics of consumer understanding of claims, acceptance as well as trust in the information presented but also the effects on vulnerable groups such as children and elderly consumers. Another field of debate was said to have been the question of the effectiveness of health claims and symbols. Lastly, stakeholders reported that public debates focussed mainly on the legislative aspects, i.e. how to apply the EU Regulation (No 1924/2006) with regards to wording issues, the evaluation process at the European Food Safety Authority (EFSA), the status of various claims and the nutrient profile modelling to be introduced in Europe.

Keywords: Health claims; health symbols; history of use; Europe.

\section{KEY INFORMANT INTERVIEWS IN THE EU MEMBER STATES}

As part of the FP7 EU-funded project CLYMBOL ("Role of health-related claims and symbols in consumer behaviour", Grant no. 311963, [1]), the objective of this pan-European study was to analyse country differences in the history of use of health claims and symbols before the introduction of the EU Regulation on Health Claims (No 1924/2006).

\subsection{Background}

Over the past decades, many countries around the world have undertaken actions to regulate the use of health claims and symbols on food products: Japan [3,4], China [5], Australia \&
New Zealand [6], the USA [7] or Canada [8], to name a few. For a recent overview, see [9].

In 2000, the European Commission made an attempt at harmonising legislation by introducing the Directive 2000/13/EC on labelling, presentation and advertising of foodstuffs [10] which prohibited attributing properties for prevention, treatment or cure of human diseases to food products but which was not consistently enforced throughout the EU [11]. After further initiatives, among others the concerted action project PASSCLAIM which developed draft guidelines for assessing the scientific substantiation of health claims [12], the Regulation (EC) No 1924/2006 was introduced, harmonising the use of nutrition and health claims in Europe. While the use of health claims is now regulated, health symbols are still subject 
to interpretation in their meaning (e.g., what is a health symbol) and use (e.g., how and when can they be used).

Prior to 2006, many European countries had different practices for allowing health claims and symbols on food products. In different countries, different types of claims were allowed (or not), on different types of products. This has led to difficulties for food producers operating across borders [11] but arguably also to a multitude of health-related messages that consumers were exposed to and that carried the potential to mislead them [13]. Furthermore, the effects of health claims, both for business and for consumer health, have been argued controversially $[14,15,16,17]$. As a result, public opinion in some countries has been favourable while it has been more hostile in others.

As such, the present study sets out to collect data on the history of use of health claims and symbols across the EU Member States, based on desk research and on 2-3 key informant interviews per country, i.e. with representatives of national food authorities, food industry federations and consumer organisations. While for health claims, the focus lies on national regulations prior to 2006, for health symbols we also looked at the current state of use and regulation, i.e. national interpretation of European law. Analysis of these data is hoped to contribute to a better understanding of the differences between EU countries with regard to the role of health claims and symbols in public health, food business but also consumer behaviour. Additionally, the interviews will be used to obtain information on existing databases of health claims and health symbols on the markets in the respective countries.

\section{RESEARCH PROTOCOL}

\subsection{Interview Protocol}

This interview protocol details the procedure that was followed, once stakeholders had been selected and recruited.

The interviews could be conducted via recorded telephone, face to face or a mixture of the two methods. They were semi-structured, with questions and prompts designed to be as openended as possible to encourage dialogue and minimise interviewer bias. The columns Background/Examples and Main objective of the question were designed to help the interviewer conduct the interview. If necessary, the wording of some of the questions could be adapted in order to explain what was meant. Interviewers could use the additional information and explanations in the Discussion Guideline in order to be as clear as possible in the interview.

All interviews lasted around 30 minutes.

\subsubsection{Before the interview}

- Gather and assimilate a brief amount of background information on the individuals and stakeholder groups to identify the interests they represent.

- Email/phone participants to invite them to the interviews (mention purpose, estimated length of the interview, confidentiality).

- Send all interviewees information about the project and the aim of the interview plus (if necessary) additional instructions via email, before the interview.

- Request the interviewee to prepare and if necessary provide factual details. They can also prepare/bring with them any documents they think might be relevant to the interview.

- Inform the interviewee that additional information or answers to questions they could not provide during the interview can be sent via email, after the interview.

- Ensure you have a document on your national/university's ethical procedures which can be shared with the interviewee, if requested. You may also have to get approval for the interview by your organisation.

- Check that all needed equipment is available and working - digital/tape recorder, spare batteries and memory cards/tapes.

- Go through the interview schedule and be prepared to tailor prompts to the interviewee.

- Pilot test with a couple of people in your work place to assess the length of the interview and to get familiarised with asking the questions.

\subsubsection{During the interview}

When recording: re-iterate the outline of the study, explain confidentiality of the information and the right to withdraw from the interview at any time. Obtain verbal consent to this and the interviewee's agreement to participate in the interview. Make sure that participants know that their names will not be used during any analysis or final written reports. All results will be anonymised. 
- Check that the tape recorder is working, ask the participant to state their name, for example.

- Follow the interview schedule (you may want to write down interesting points in case parts of the recording are difficult to understand, due to quality or volume reasons).

- Use the prompts given in the Background/ Examples column of the discussion guideline. If necessary, adapt the wording of the questions, as long as the content of the question remains the same.

\subsubsection{Structure of the Interview}

1) History of the use of health claims and health-related symbols.

a. Health claims

b. Health symbols

2) Monitoring health claims and symbols.

3) Measuring impact of health claims and symbols.

4) Stakeholder perception.

\subsubsection{After the interview}

- Check that the recording has worked.

- Write an email or letter of thanks to the participant or participant organisation, following up any actions.

- Transcribe tapes.

- Summarise the answer/findings to each question, using the grid (Excel file) that has been provided to you. This shall be done in English, regardless of which language the interview took place in.

- Fill out sample data table (who was asked for an interview, who declined and who accepted (and which type of stakeholder: national authority, industry representative or consumer organisation)).

- Send all documents to EUFIC as task leader. Keep the recording and transcription of all interviews stored, in case questions arise in the reporting process.

\subsection{Sample Data}

Interviewers were asked to complete the following details about their interview participants for the purpose of reporting the response rates for the Stakeholder Interviews (Table 2).

\section{Table 1. Standard introduction}

Audio recorder: Thank you for agreeing to be interviewed today. So that I can analyse your off responses fully, I would like to audio record this interview. I can assure you that all data collected from you will be held and processed in the strictest confidence in accordance with the Data Protection Act (1998), and neither you nor your organisation will be named or identifiable in any report issuing from this research. I am now going to turn on the audio recorder

Audio recorder: Can you confirm if you are you happy for the interview to be audio recorded? on (await response from interviewee) Are you happy with the explanation I have given you about the nature, and purpose of this study and of what is expected of you? Do you have any further questions or is there anything you don't understand? (await response from interviewee) Are you aware that you are free to withdraw from the study at any time without needing to justify your decision? (await response from interviewee) (Commence questioning from the agreed discussion guideline)

Table 2. Sample data

\begin{tabular}{llll}
\hline & $\begin{array}{l}\text { National } \\
\text { food } \\
\text { authority }\end{array}$ & $\begin{array}{l}\text { Industry } \\
\text { representative }\end{array}$ & $\begin{array}{l}\text { Consumer } \\
\text { organisation }\end{array}$ \\
\hline $\begin{array}{l}\text { How many people were approached for the } \\
\text { interviews? }\end{array}$ & & \\
How many refused to participate? & & \\
How many interviews were conducted/people & & \\
accepted to participate? & & \\
\hline
\end{tabular}


Table 3. Discussion guideline

\section{Question}

Background / Examples

Main objective of the question

History of the use of health claims and health-related symbols

Introduce the topic of the interview, use the standard introduction. If necessary, have the terms of reference and the excerpts from legislation handy.

1) Can you elaborate on the national regulatory process regarding health claims that was in place in your country, prior to the 2006 Regulation?

2) If any, which voluntary codes of practice were in use for health claims? (e.g., preapproval vs. justification)

\section{Additionally:}

3) If you can remember - on which food and drink products /categories could one find health claims, prior to the 2006 Regulation?

4) What types of health claims were in use?

5) Are there currently any health symbols that can be found on food and drink products? If so, which ones?

6) In your country, how is the use of health symbols regulated? Have there been any major regulatory changes in the past years?

\section{Health claims}

Focus lies on label communication but if information is available on public campaigns etc., this can be noted down, too.

Voluntary codes of practice could include:

- Pre-approval (having to seek permission before using claim on product)

- Justification (justifying use of claim only when challenged)

Only if interviewee knows. Information can also be provided via Email afterwards.

Types of claims refer to the benefits they address: digestive,

cardiovascular, immune function, bone density etc.

\section{Health symbols}

Examples for health symbols include: Choices logo, Nordic Keyhole,

Toothfriendly logo, Blue Angel (Germany), Pick the Tick (Australia) etc. $\rightarrow$ Brand names (e.g. Weight Watchers, Slim fit) are excluded from this research
Insights on history of use and regulation of health claims.

Prior to the 2006 Regulation, the Directive 2000/13/EC (labelling, presentation and advertising of foodstuffs) could be interpreted differently by EU States. Question 1 aims at collecting information on this legislative interpretation.

What claims were used and how/for which purpose?

Insights on history of use and possible regulation of health symbols.

What symbols exist on the national market?

Which themes (benefits) are these symbols mainly associated with?

7) If no official regulation, is 
there a voluntary code of practice when using health symbols on products? (e.g., pre-approval vs. justification)
Voluntary codes of practice could include:
- Pre-approval (having to seek permission before using symbol on product)
- Justification (justifying use of symbol only when challenged)

\section{Additionally,}

8) If any - on which food and drink products /categories can health symbols currently

Only if interviewee knows. Information can also be provided via Email be found?

9) What were the main themes associated with those symbols?

afterwards.

Possible themes, in the sense of health benefits: general health cardiovascular, dental etc.

$$
\text { Monitoring claims and symbols }
$$

10) Are food operators required to report their use of health claims and symbols to national authorities? (if yes are databases of claims and symbols (publicly) available and could we gain access?)

11) Do you think such databases are complete?

\section{Data bases could comprise of products bearing health claims and/or} symbols, their wording/design and additional nutritional information; How are claims and symbols currently on the product

\section{Regulation 1924/2006:}

\section{Article 25: Monitoring}

To facilitate efficient monitoring of foods bearing nutrition or health claims, Member States may require the manufacturer or the person placing such foods on the market in their territory to notify the competent authority of that placing on the market by forwarding to it a model of the label used for the product.

\section{Measuring the impact of claims and symbols}

12) Do you see the need to measure the societal/ economic impact of

a) of health claims?

b) of health symbols? Possible impacts: health outcomes, national consumption behaviour, consumer trust, product sales, manufacturers' reputation etc.

For each topic named by the interviewee, ask the follow-up "and how should this be measured?"

13) If so, how could/should this be measured?

Different measurements: how quick (simple measurements vs. detailed methodologies), how accurate (averages or in-depth analyses of

Methodological requirements could be specified for WP3 - what is needed in terms of measurement. 
different consumer strata) and for what cost (panels, online surveys,

experimental research, interviews etc.)

$\rightarrow$ If the answers differ between claims and symbols, please note down accordingly, in the grid.

\section{Stakeholder perception}

The outcome of these questions will be of added-value for later WPs but may have to be cut short due to time constraints.

14) What has been the Stakeholder groups: national authorities, food industry representatives,

nature of the stakeholder consumer organisations, media/journalists, researchers, public figures and others

debate, concerning

a) health claims?

b) health symbols?

15) Which themes dominate the public debate

a) with regard to health

claims?

b) with regard to health symbols?

\section{Public refers to the reporting in media and the subsequent general} attention given to the topic.

Possible themes: necessary for overweight consumers but not for those with a varied/balanced diet; elderly consumers, mothers and other specific consumer groups; based on certain nutrient profiles; what product categories should not be allowed to have health claims on; depth and specificity of scientific support for a health claim; consumer understanding of EFSA wording 


\subsection{Standard Introduction for All
Interviews}

\subsubsection{Introduction}

"This interview is part of CLYMBOL - Role of health-related claims and symbols in consumer behaviour - a European research project partly funded by the European Commission".

\subsubsection{Data use and security}

Interviewers explained confidentiality, the right to withdraw from the study and obtain verbal consent to participate. They further ensured that participants knew their interview data would be anonymised during analysis or final reports (Table 1).

\subsubsection{CLYMBOL}

"The objective of this project is to determine how health-related claims and symbols are understood by consumers and how they affect purchasing and consumption, taking into account both individual and country-specific differences".

\subsubsection{Aim of the interview}

"We want to better understand how the national health claims landscape looked like, prior to the 2006 Regulation issued on European level. We further want to gather insights on how the use of health symbols is being interpreted, based on European law. Our objective is to analyse country differences in the history of use of health claims and symbols by interviewing key informants/ experts in the EU Member States. Stakeholders include national food authorities, national industry representatives and consumer organisations".

\subsubsection{Background for this task}

"Different EU countries have had different practices in allowing health claims on food products previous to the recent legislation, and also health symbols initiatives have had mostly national origins. Likewise, food manufacturers and retailers have differed in the extent to which they have launched products with health claims and symbols on. As a result, the prerequisites for understanding health claims and symbols and for their effects on purchasing and consumption could differ between countries".

\section{INTERVIEWS}

It is to be noted that these interview results are based on an individual opinion/evaluation and do not necessarily reflect the organisation's view as a whole, nor that of the authors.

\subsection{Summary of Findings}

\subsubsection{Country differences}

Prior to 2006, health claims were reported to have been (at least partially) regulated on national level in half (13) of the EU Member States interviewed. The same number of countries reported no specific national legislation or regulatory process in place. Seven Member States additionally mentioned the Directive 2000/13/EC as a supra-national legislative act which prohibits any "labelling, presentation and advertising of foodstuffs" which could mislead consumers. It appears that this Directive was seen as a partial 'regulation' in the area of health claims, prior to 2006.

Of those countries who reported a regulatory process in place, health claims were generally allowed in two countries while they were prohibited in three other. It is noteworthy that some stakeholders interviewed mentioned that claims could still be found on food products, despite such legislation. The remaining eight Member States reported the prohibition of selected types of claims, mainly disease risk reduction.

Lastly, voluntary codes of practice were reported to have been in use in twelve Member States, prior to the Health Claims Regulation. This includes "justification when challenged" and preapproval via national institutions. The remaining fourteen countries reported no such codes of practice in place.

Concerning health symbols, only interviewees in Belgium, Spain and Sweden reported the use as being regulated. In total, eight Member States mentioned some form of voluntary code of practice which could be executed either on government level or via private organisations. The eighteen remaining Member States reported no regulation of any kind.

All interview summaries regarding country differences are presented in the Supplementary Material (Tables 1 and 2). 
Table 4. Sample overview

\begin{tabular}{|c|c|c|c|c|c|}
\hline Country & Stakeholder & Response & Non-response & Date & Response rate \\
\hline \multirow[t]{3}{*}{ Austria } & NFA & + & - & $26 / 02 / 13$ & $2 / 3$ \\
\hline & $\mathrm{CO}$ & + & - & $18 / 03 / 13$ & \\
\hline & IR & - & n.a. & - & \\
\hline \multirow[t]{3}{*}{ Belgium } & NFA & + & - & $27 / 02 / 13$ & $3 / 3$ \\
\hline & $\mathrm{CO}$ & + & - & $21 / 03 / 13$ & \\
\hline & IR & + & - & $28 / 03 / 13$ & \\
\hline \multirow{3}{*}{ Bulgaria } & NFA & + & - & $18 / 03 / 13$ & $2 / 3$ \\
\hline & $\mathrm{CO}$ & + & - & $08 / 03 / 13$ & \\
\hline & IR & - & n.e. & - & \\
\hline \multirow[t]{3}{*}{ Croatia } & NFA & - & n.a. & - & $2 / 3$ \\
\hline & $\mathrm{CO}$ & + & - & $14 / 03 / 13$ & \\
\hline & IR & + & - & $13 / 03 / 13$ & \\
\hline \multirow[t]{3}{*}{ Cyprus } & NFA & - & n.a. & - & $0 / 3$ \\
\hline & $\mathrm{CO}$ & - & n.a. & - & \\
\hline & IR & - & n.e. & - & \\
\hline Czech & NFA & - & n.a. & - & $1 / 3$ \\
\hline \multirow{2}{*}{ Republic } & $\mathrm{CO}$ & - & n.e. & - & \\
\hline & IR & + & - & $22 / 02 / 13$ & \\
\hline \multirow[t]{3}{*}{ Denmark } & NFA & + & - & 07/03/13 & $2 / 3$ \\
\hline & $\mathrm{CO}$ & - & n.a. & - & \\
\hline & IR & + & - & 06/03/13 & \\
\hline \multirow[t]{3}{*}{ Estonia } & NFA & + & - & $14 / 06 / 13$ & $1 / 3$ \\
\hline & $\mathrm{CO}$ & - & n.a. & - & \\
\hline & IR & - & n.a. & - & \\
\hline \multirow[t]{3}{*}{ Finland } & NFA & + & - & $11 / 06 / 13$ & $1 / 3$ \\
\hline & $\mathrm{CO}$ & - & n.a. & - & \\
\hline & IR & - & n.a. & - & \\
\hline \multirow[t]{3}{*}{ France } & NFA & - & n.a. & - & $2 / 3$ \\
\hline & $\mathrm{CO}$ & + & - & $07 / 03 / 13$ & \\
\hline & IR & + & - & $15 / 03 / 13$ & \\
\hline \multirow[t]{3}{*}{ Germany } & NFA & + & - & $27 / 02 / 13$ & $2 / 3$ \\
\hline & $\mathrm{CO}$ & - & n.a. & - & \\
\hline & IR & + & - & $19 / 02 / 13$ & \\
\hline \multirow[t]{3}{*}{ Greece } & NFA & + & - & $20 / 03 / 13$ & $3 / 3$ \\
\hline & $\mathrm{CO}$ & + & - & $27 / 03 / 13$ & \\
\hline & IR & + & - & $02 / 04 / 13$ & \\
\hline \multirow[t]{3}{*}{ Hungary } & NFA & + & - & $14 / 05 / 13$ & $3 / 3$ \\
\hline & NFA & + & - & $14 / 05 / 13$ & \\
\hline & CO/IR & + & - & $15 / 05 / 13$ & \\
\hline \multirow[t]{3}{*}{ Ireland } & NFA & + & - & $26 / 02 / 13$ & $1 / 3$ \\
\hline & $\mathrm{CO}$ & - & n.a. & - & \\
\hline & IR & - & n.a. & - & \\
\hline \multirow[t]{3}{*}{ Italy } & NFA & + & - & $27 / 05 / 13$ & $3 / 3$ \\
\hline & $\mathrm{CO}$ & + & - & $22 / 03 / 13$ & \\
\hline & IR & + & - & $30 / 04 / 13$ & \\
\hline \multirow[t]{3}{*}{ Latvia } & NFA & - & n.a. & - & $1 / 3$ \\
\hline & $\mathrm{CO}$ & + & - & $05 / 04 / 13$ & \\
\hline & IR & - & n.a. & - & \\
\hline \multirow[t]{3}{*}{ Lithuania } & NFA & + & - & $14 / 06 / 13$ & $1 / 3$ \\
\hline & $\mathrm{CO}$ & - & n.a. & - & \\
\hline & IR & - & n.a & - & \\
\hline \multirow{3}{*}{ Luxembourg } & NFA & - & n.a. & - & $0 / 3$ \\
\hline & $\mathrm{CO}$ & - & n.a. & - & \\
\hline & IR & - & n.a. & - & \\
\hline
\end{tabular}




\begin{tabular}{|c|c|c|c|c|c|}
\hline Country & Stakeholder & Response & Non-response & Date & Response rate \\
\hline \multirow[t]{3}{*}{ Malta } & NFA & + & - & $13 / 02 / 13$ & $1 / 3$ \\
\hline & $\mathrm{CO}$ & - & n.a. & - & \\
\hline & IR & - & - & - & \\
\hline The & NFA & + & - & $22 / 02 / 13$ & $3 / 3$ \\
\hline \multirow[t]{2}{*}{ Netherlands } & $\mathrm{CO}$ & + & - & $06 / 03 / 13$ & \\
\hline & IR & + & - & $22 / 02 / 13$ & \\
\hline \multirow[t]{3}{*}{ Poland } & NFA & + & - & $15 / 03 / 13$ & $2 / 3$ \\
\hline & $\mathrm{CO}$ & - & n.a. & - & \\
\hline & IR & + & - & $02 / 04 / 13$ & \\
\hline \multirow[t]{3}{*}{ Portugal } & NFA & + & - & $05 / 04 / 13$ & $2 / 3$ \\
\hline & $\mathrm{CO}$ & + & - & $21 / 03 / 13$ & \\
\hline & IR & - & n.a. & - & \\
\hline \multirow[t]{3}{*}{ Romania } & NFA & + & - & $07 / 02 / 13$ & $3 / 3$ \\
\hline & $\mathrm{CO}$ & + & - & $21 / 02 / 13$ & \\
\hline & IR & + & - & $26 / 02 / 13$ & \\
\hline \multirow[t]{3}{*}{ Slovakia } & NFA & + & - & $22 / 05 / 13$ & $3 / 3$ \\
\hline & $\mathrm{CO}$ & + & - & $06 / 06 / 13$ & \\
\hline & IR & + & - & $05 / 06 / 13$ & \\
\hline \multirow[t]{3}{*}{ Slovenia } & NFA & + & - & $11 / 03 / 13$ & $3 / 3$ \\
\hline & $\mathrm{CO}$ & + & - & $14 / 03 / 13$ & \\
\hline & IR & + & - & $12 / 03 / 13$ & \\
\hline \multirow[t]{3}{*}{ Spain } & NFA & + & - & $28 / 05 / 13$ & $3 / 3$ \\
\hline & $\mathrm{CO}$ & + & - & $19 / 03 / 13$ & \\
\hline & IR & + & - & $27 / 05 / 13$ & \\
\hline \multirow[t]{3}{*}{ Sweden } & NFA & + & - & $14 / 07 / 13$ & $1 / 3$ \\
\hline & $\mathrm{CO}$ & - & n.a. & - & \\
\hline & IR & - & n.a. & - & \\
\hline United & NFA & + & - & $15 / 02 / 13$ & $2 / 3$ \\
\hline \multirow{2}{*}{ Kingdom } & $\mathrm{CO}$ & - & n.e. & - & \\
\hline & $\mathrm{CO}$ & + & - & $22 / 02 / 13$ & \\
\hline
\end{tabular}

NFA: National Food Authority, CO: Consumer Organisation, IR: Industry Representative

n.a.: not available, n.e.: no expertise

The criteria for classification (Table 5) were defined as follows:

Having national regulation for health claims in place refers to one of the following:

a) No specific legislation on health claims, but other laws mentioned (e.g. food-labelling and marketing-related) to have regulated (some) aspects of the health claims use: Austria, Belgium, Germany, Italy, Netherlands, Romania, Spain.

b) Claims allowed in general or no specific national regulation reported; however, some claim types or specific mentions prohibited (e.g. on the basis of interpretation of the existing EU legislative acts and national legislation): Denmark, Estonia, Finland, Portugal.

c) Health claims not allowed: Austria (as of 2003), Greece, Slovenia.

Existence of voluntary codes for health claims refers to one of the following: a) Pre-approval by the governmental or private bodies: Croatia, Finland, Netherlands, Sweden.

b) Justification when challenged: Belgium, Bulgaria, Croatia, France, Greece, Hungary, Netherlands, Poland.

c) Voluntary agreements on use (e.g. listing allowed statements): Belgium, Spain, Sweden, UK.

Having national regulation for health symbols refers to one of the following:

a) No specific legislation on health symbols, but other laws mentioned (e.g. on foodadvertisement, food safety) to regulate some aspects of the health symbols use: Belgium, Spain.

b) National regulation for the 'Swedish Keyhole' symbol: Sweden.

Existence of voluntary codes for health symbols refers to one of the following: 
a) Pre-approval by the governmental or private bodies: Czech Republic, Denmark, Finland, Netherlands, Portugal, UK.

b) Justification when challenged: Hungary, Poland.

Absence of national regulation on health claims and symbols refers to: not mentioning any national regulation, reporting "no specific regulation" or only mentioning EU legislative acts. Absence of voluntary codes for health claims and symbols refers to not mentioning any or reporting "no voluntary codes of practice".

According to the interviews, prior to 2006, health claims were mainly found on food supplements. An equally large proportion of claims was reported to have been used for dairy and fermented products.

The main types of claims were said to have revolved around heart health (blood, cardiovascular diseases, and cholesterol- lowering effects), digestion, the immune system, bone health, and general health and well-being. Claims relating to growth in children were also mentioned.

The main health symbols that were reported throughout the Member States are the Dutch Choices logo, the Swedish Keyhole, toothfriendly logos and a variation of heart symbols, often issued by national heart foundations.

Main themes associated with symbols were said to be general health and "better choice", heart health, dental health, bone health and weight loss.

Stakeholders from the EU Member States reported health symbols to be mainly found on margarine and edible fats/spreads products, e.g. in conjunction with claims around omega-3 fatty acids. Dairy products were also mentioned as being very likely to carry such symbols.

Table 5. Overview of country differences in the history of use of claims and symbols

\begin{tabular}{|c|c|c|c|}
\hline & & Health claims (prior to 2006) & Health symbols \\
\hline \multirow[t]{2}{*}{$\begin{array}{l}\text { National } \\
\text { regulation in } \\
\text { place }\end{array}$} & Yes & $\begin{array}{l}\text { Austria, Belgium, Denmark, } \\
\text { Estonia, Finland, Germany, } \\
\text { Greece, Italy, Netherlands, } \\
\text { Portugal, Romania, Slovenia, } \\
\text { Spain }\end{array}$ & Belgium, Spain, Sweden (Keyhole) \\
\hline & No**** & $\begin{array}{l}\text { Bulgaria, Croatia, Czech } \\
\text { Republic, France, Hungary, } \\
\text { Ireland, Latvia, Lithuania, Malta, } \\
\text { Poland, Slovakia, Sweden, UK }\end{array}$ & $\begin{array}{l}\text { Austria, Bulgaria, Croatia, Czech } \\
\text { Republic, Denmark, Estonia, Finland, } \\
\text { France, Germany, Greece, Hungary, } \\
\text { Ireland, Italy, Latvia, Lithuania, Malta, } \\
\text { Netherlands, Poland, Portugal, } \\
\text { Romania, Slovakia, Slovenia, UK }\end{array}$ \\
\hline \multirow{2}{*}{$\begin{array}{l}\text { Voluntary codes } \\
\text { of practice in use } \\
\text { (pre-approval or } \\
\text { justification when } \\
\text { challenged) }\end{array}$} & Yes & $\begin{array}{l}\text { Belgium, Bulgaria, Croatia, } \\
\text { Finland, France, Greece, } \\
\text { Hungary, Netherlands, Poland, } \\
\text { Spain, Sweden, UK }\end{array}$ & $\begin{array}{l}\text { Hungary, Poland, Portugal, Czech } \\
\text { Republic, Denmark, Finland, } \\
\text { Netherlands, UK *** }\end{array}$ \\
\hline & No & $\begin{array}{l}\text { Austria, Czech Republic, } \\
\text { Denmark, Estonia, Germany, } \\
\text { Ireland, Italy, Latvia, Lithuania, } \\
\text { Malta, Portugal, Romania, } \\
\text { Slovakia, Slovenia }\end{array}$ & $\begin{array}{l}\text { Austria, Belgium, Bulgaria, Croatia, } \\
\text { Estonia, France, Germany, Greece, } \\
\text { Ireland, Italy, Latvia, Lithuania, Malta, } \\
\text { Romania, Slovakia, Slovenia, Spain, } \\
\text { Sweden }\end{array}$ \\
\hline
\end{tabular}

* With regard to health claims, the following countries only mentioned the Directive 2000/13/EC in place, prohibiting any "labelling, presentation and advertising of foodstuffs" which could mislead consumers: Bulgaria, Croatia, Czech Republic, Ireland, Poland, Slovakia and United Kingdom.

** With regard to health symbols, the following countries only mentioned the Regulation 1924/2006 on health and nutrition claims: Czech Republic, Denmark, France, Germany, Greece, Hungary, Malta, Netherlands, Poland, Slovenia and United Kingdom.

*** Voluntary codes of practice issued by private bodies, not on governmental level (e.g. Heart Foundation, Diabetes Association, Public health organisations, retailers) 


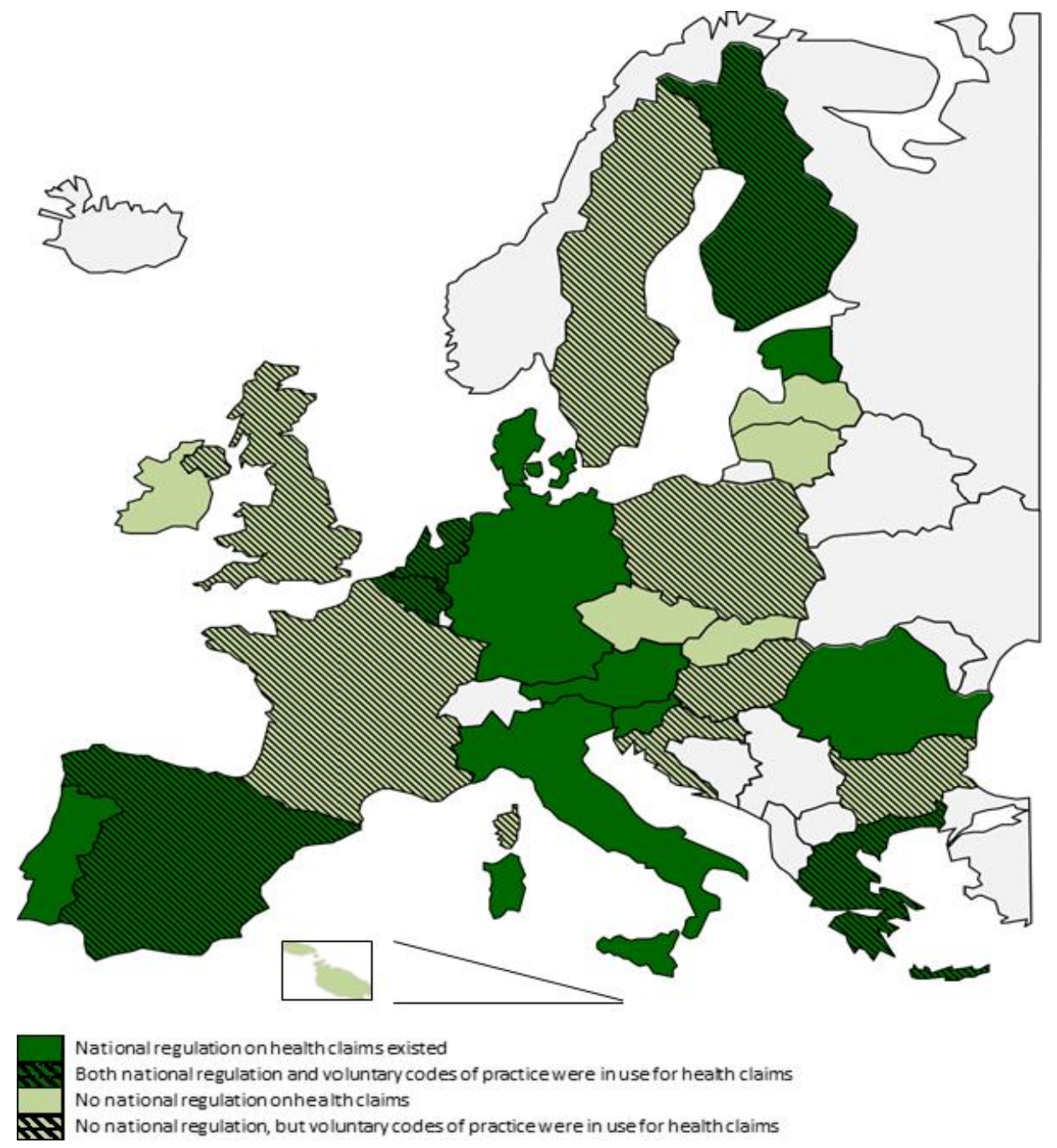

Fig. 1. Regulation of health claims in the EU Member States (prior to 2006)

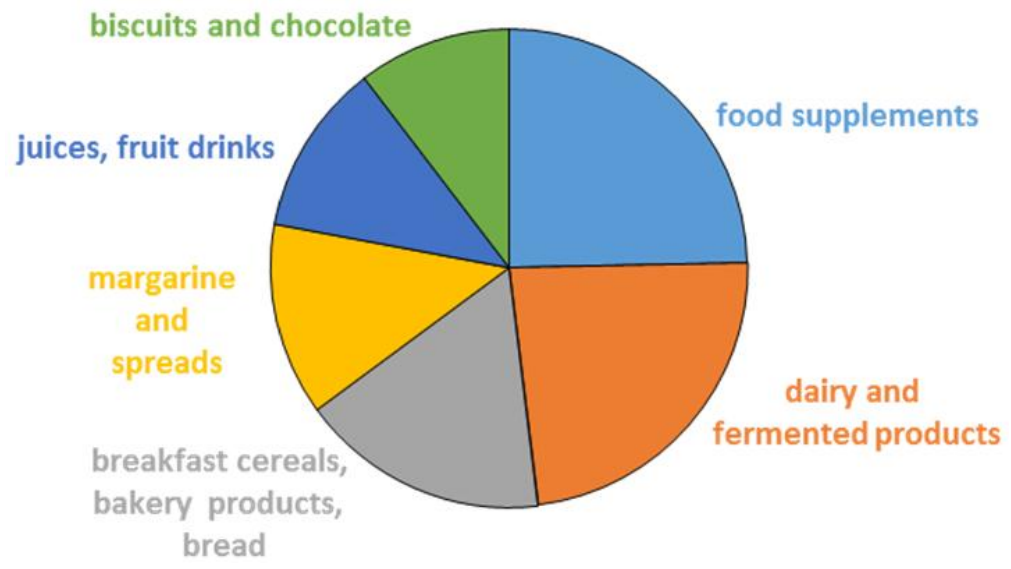

Fig. 2. Food categories most frequently mentioned to bear health claims in the EU (prior to 2006) 
Table 6. Country-specific information on regulation/voluntary codes regarding health claims

\begin{tabular}{|c|c|c|}
\hline Country & National regulation & Voluntary code of practice \\
\hline Austria & $\begin{array}{l}\text { Mandatory to approve claims regarding } \\
\text { correctness and appropriateness. } \\
\text { Health claims prohibited as of } 2003 \text {. }\end{array}$ & n.c. \\
\hline Belgium & $\begin{array}{l}\text { Certain words, pictures and references } \\
\text { prohibited in food marketing and } \\
\text { labelling. }\end{array}$ & $\begin{array}{l}\text { Indicative positive list of allowed claims } \\
\text { existed. Claims had to be justified only } \\
\text { when challenged. }\end{array}$ \\
\hline Bulgaria & $\begin{array}{l}\text { Health claims allowed. Medical claims } \\
\text { prohibited. }\end{array}$ & To be justified only when challenged. \\
\hline Croatia & n.r. & $\begin{array}{l}\text { Pre-approval by the Ministry of Health. } \\
\text { Claims had to be additionally justified when } \\
\text { challenged. }\end{array}$ \\
\hline $\begin{array}{l}\text { Czech } \\
\text { Republic }\end{array}$ & n.r. & n.c. \\
\hline Denmark & $\begin{array}{l}\text { Claims on wellness or physiological } \\
\text { effects allowed if scientifically proven. } \\
\text { Disease risk reduction claims } \\
\text { prohibited. }\end{array}$ & n.c. \\
\hline Estonia & $\begin{array}{l}\text { Claims referring to the risk of disease } \\
\text { were not allowed. }\end{array}$ & n.c. \\
\hline Finland & $\begin{array}{l}\text { Claims linked to preventing, treating or } \\
\text { curing were prohibited. Claims on } \\
\text { disease risk reduction allowed. }\end{array}$ & $\begin{array}{l}\text { A council of experts assessed the health } \\
\text { claims proposed by the food companies. }\end{array}$ \\
\hline France & n.r. & To be justified only when challenged. \\
\hline Germany & $\begin{array}{l}\text { Scientifically unsubstantiated } \\
\text { information and claims on disease risk } \\
\text { reduction or the immune system } \\
\text { prohibited. }\end{array}$ & n.c. \\
\hline Greece & Health claims were not allowed. & To be justified only when challenged. \\
\hline $\begin{array}{l}\text { Hungary } \\
\text { Ireland }\end{array}$ & & \\
\hline Italy & $\begin{array}{l}\text { Claims referring to disease risk } \\
\text { reduction prohibited. }\end{array}$ & n.c. \\
\hline Latvia & n.r. & n.c. \\
\hline Lithuania & n.r. & n.c. \\
\hline Malta & n.r. & n.c. \\
\hline $\begin{array}{l}\text { The } \\
\text { Netherlan } \\
\text { ds }\end{array}$ & $\begin{array}{l}\text { Health claims allowed. Medical claims } \\
\text { prohibited. }\end{array}$ & $\begin{array}{l}\text { Private body organized by the food } \\
\text { (supplements) industry revised claim } \\
\text { wordings. National nutrition experts } \\
\text { reviewed scientific substantiation of health } \\
\text { claims. Claims had to be additionally } \\
\text { justified when challenged. }\end{array}$ \\
\hline Poland & n.r. & To be justified only when challenged. \\
\hline Portugal & $\begin{array}{l}\text { Claims referring to disease risk } \\
\text { reduction prohibited. }\end{array}$ & n.c. \\
\hline Romania & $\begin{array}{l}\text { Claim approval within the product } \\
\text { approval procedure. }\end{array}$ & n.c. \\
\hline Slovakia & n.r. & n.c. \\
\hline Slovenia & $\begin{array}{l}\text { Health claims prohibited (considered as } \\
\text { medicinal claims). }\end{array}$ & n.c. \\
\hline Spain & $\begin{array}{l}\text { Forbidden to link foods to weight } \\
\text { management, physical, psychological, } \\
\text { sportive or sexual performance. }\end{array}$ & $\begin{array}{l}\text { Voluntary agreement between the } \\
\text { authorities and food industry on advertising } \\
\text { and publicity. }\end{array}$ \\
\hline
\end{tabular}




\begin{tabular}{|c|c|c|}
\hline Country & National regulation & Voluntary code of practice \\
\hline Sweden & n.r. & $\begin{array}{l}\text { Voluntary code of practice excluded food } \\
\text { supplements. Panel of experts to confirm } \\
\text { scientific substantiation of physiological } \\
\text { claims. Assessment board to monitor } \\
\text { compliance of marketing/labelling with the } \\
\text { code. }\end{array}$ \\
\hline $\begin{array}{l}\text { United } \\
\text { Kingdom }\end{array}$ & Medicinal claims prohibited. & $\begin{array}{l}\text { A body consisting of all stakeholders } \\
\text { defined statements that could be used as a } \\
\text { basis for health and nutrition claims. }\end{array}$ \\
\hline
\end{tabular}

n.r. No regulation

n.c. No voluntary code of practice

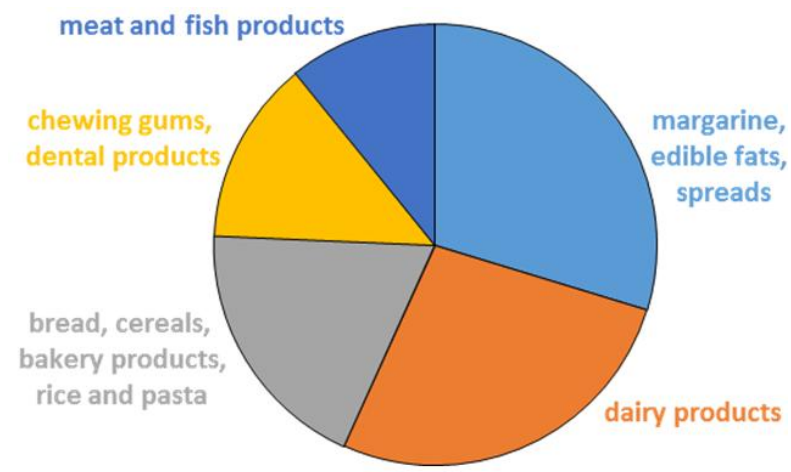

Fig. 3. Food categories most frequently mentioned to bear health symbols in the EU

Table 7. Most common health symbols reported on, in the EU (current situation)

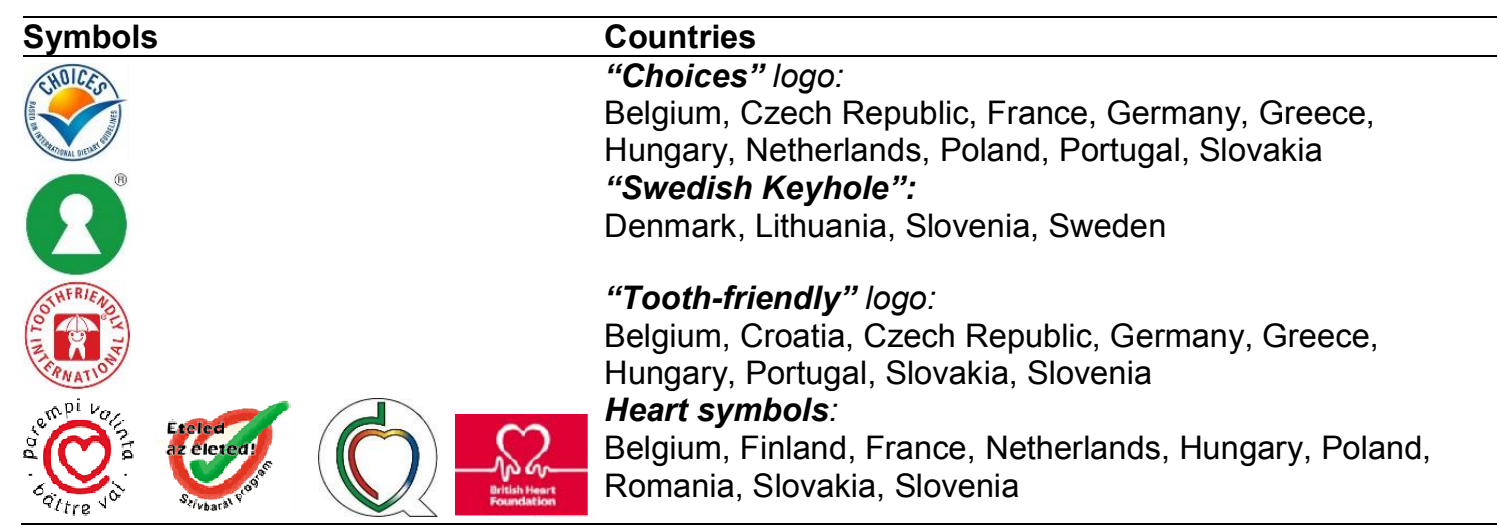

In addition to the health symbols presented in Table 7, further logos were mentioned during the interviews (Table 8). As per CLYMBOL definitions, some of these are not seen as health symbols. Those in bold have been grouped into an additional claim type: health-related ingredient claims.

\subsubsection{Monitoring health claims and symbols}

Only three Member States declared national mandatory reporting: in Portugal, health symbols were said to be monitored systematically, while in Slovenia, authorities mentioned health claims to be monitored. Only Italian stakeholders unanimously reported a mandatory reporting of both health claims and symbols.

The remaining Member States stated no reporting on the use of health claims and symbols. In several interviews, product launches but also specific production technologies (e.g. GMO) were mentioned as being mandatory to report. However, these are not necessarily related to the use of health claims and symbols. 
Databases on health claims and symbols were said to be established only in six Member States, while in two countries some form of data (or lists) exist of which information on health claims and symbols could be extracted. However, according to the interviewees, none of these databases are complete and many of them were said to not be up-to-date.

Table 8. Other logos mentioned in the interviews

\begin{tabular}{ll}
\hline Symbols & Countries \\
\hline Private logos issued by retailers and & Austria, Bulgaria, Czech Republic, Lithuania, \\
organisations/experts & Netherlands, Poland, Portugal, Spain, UK \\
Suitability for babies, children and mothers & Belgium, Poland, Portugal \\
"Slim female waist" and similar logos & France, Romania, Slovenia \\
"Whole grain" symbols by Nestle and other & Belgium, Denmark, UK \\
Salt-reduction related logos & Hungary, Italy \\
Traffic lights & Hungary \\
"6-a-day" & Denmark \\
"Fish twice a day" & Denmark \\
"5-a-day" & United Kingdom \\
"Arrow" indicating digestive health & France \\
"Best from the test" & Netherlands \\
"KemaKeur" & Netherlands \\
Bone symbol & Romania \\
"Protect the health" & Slovenia \\
\hline
\end{tabular}

Table 9. Monitoring of health claims and symbols

\begin{tabular}{|c|c|c|}
\hline Topic & $\begin{array}{l}\text { Type of } \\
\text { answer }\end{array}$ & Countries \\
\hline $\begin{array}{l}\text { Reporting the use of } \\
\text { health claims/symbols }\end{array}$ & $\begin{array}{l}\text { Mandatory } \\
\text { Not } \\
\text { mandatory }\end{array}$ & $\begin{array}{l}\text { Italy, Portugal }^{* *}, \text { Slovenia***} \\
\text { Austria, Belgium, Bulgaria, Croatia, Czech Republic, } \\
\text { Denmark, Estonia, Finland, France, Germany, Greece, } \\
\text { Hungary, Ireland, Latvia, Lithuania, Malta, Netherlands, } \\
\text { Poland, Romania, Slovakia***, Spain, Sweden, United } \\
\text { Kingdom }\end{array}$ \\
\hline $\begin{array}{l}\text { Databases on health } \\
\text { claims/symbols } \\
\text { available* }^{*}\end{array}$ & $\begin{array}{l}\text { Yes } \\
\text { Some } \\
\text { No }\end{array}$ & $\begin{array}{l}\text { Belgium, Czech Republic, Netherlands**, Portugal**, } \\
\text { Romania, Slovenia } \\
\text { Poland, Sweden } \\
\text { Austria, Bulgaria, Croatia, Denmark, Estonia, Finland, } \\
\text { France, Germany, Greece, Hungary, Ireland, Italy, Latvia, } \\
\text { Lithuania, Malta, Slovakia, Spain, United Kingdom }\end{array}$ \\
\hline
\end{tabular}

Table 10. Overview of existing databases

\begin{tabular}{|c|c|}
\hline Country & Database* \\
\hline Belgium & $\begin{array}{l}\text { List of food claims; On-line database on health and nutrition claims and } \\
\text { database on products carrying the Choices logo }\end{array}$ \\
\hline Czech Republic & Internal database on health claims \\
\hline The Netherlands & Database of products carrying the Choices logo \\
\hline Poland & Database on novel food supplements (with health information) \\
\hline Portugal & Database on symbols (currently being evaluated) \\
\hline Romania & Database on health and nutrition claims \\
\hline Slovenia & Database on health claims; Private database on drugs and supplements \\
\hline Sweden & Commercial database (outdated) \\
\hline
\end{tabular}




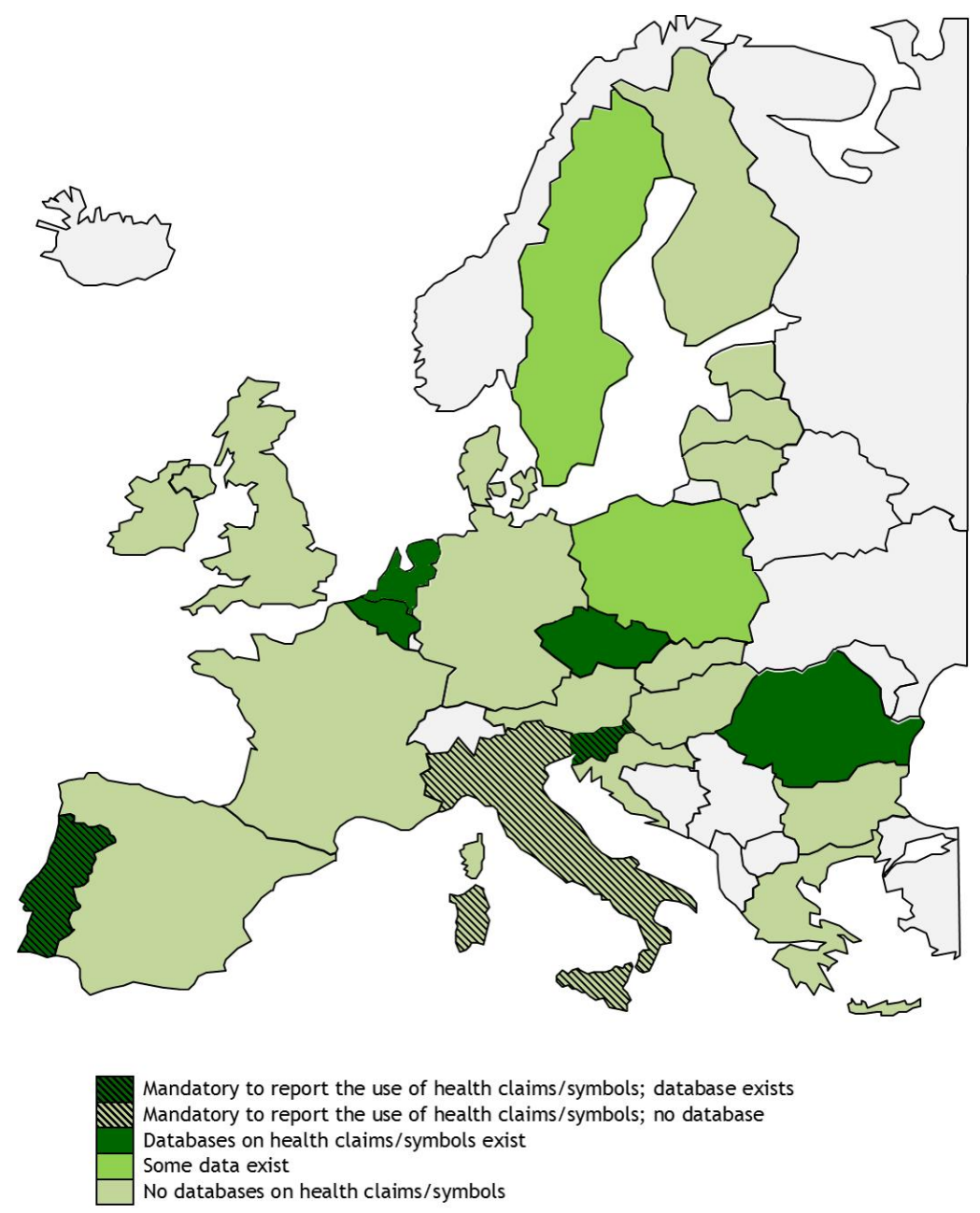

Fig. 4. Reporting and databases on health claims/symbols in the EU Member States

All interview summaries regarding the monitoring of claims and symbols are presented in the Supplementary Material (Table 3).

\subsubsection{Measuring the impact of health claims and symbols}

The majority of EU Member States expressed a strong interest in measuring the impact of health claims and symbols. The main areas of interest could be identified as consumer research (awareness and understanding of claims and symbols but also attitudes towards such information and possible effects on food choice, purchase and consumption), research into public health (health outcomes or changes in the national health status due to the use of health claims and symbols) and the analysis of the economic impact (prevalence, effect on sales, cost-benefit aspects). Methodologies mentioned to measure such impact include but are not limited to surveys, in-store observation, purchase simulation, focus groups and the analysis of sales data.

However, in some countries, different views were expressed by different stakeholders. Those opposing such measurements gave a range of reasons, including doubts over the effectiveness of claims and symbols in general but also lack of know-how, responsible authorities and resources. It was further argued by some stakeholders, that measuring the impact of claims and symbols is not necessary, for various reasons (see Table 11).

All interview summaries regarding the measurement of the impact of claims and symbols are presented in the Supplementary Material (Table 4). 
Table 11. Measuring the impact of health claims and symbols

\begin{tabular}{ll}
\hline & Country \\
\hline In favour & Austria, Belgium, Bulgaria, Croatia, Denmark, Finland, France, \\
& Germany, Hungary, Italy, Latvia, Lithuania, Malta, Poland, Portugal, \\
& Romania, Slovenia, Sweden \\
Sceptical & Czech Republic, Estonia \\
Opposing views & Greece, Netherlands, Slovakia, Spain \\
No clear answer was given & Ireland, UK \\
\hline
\end{tabular}

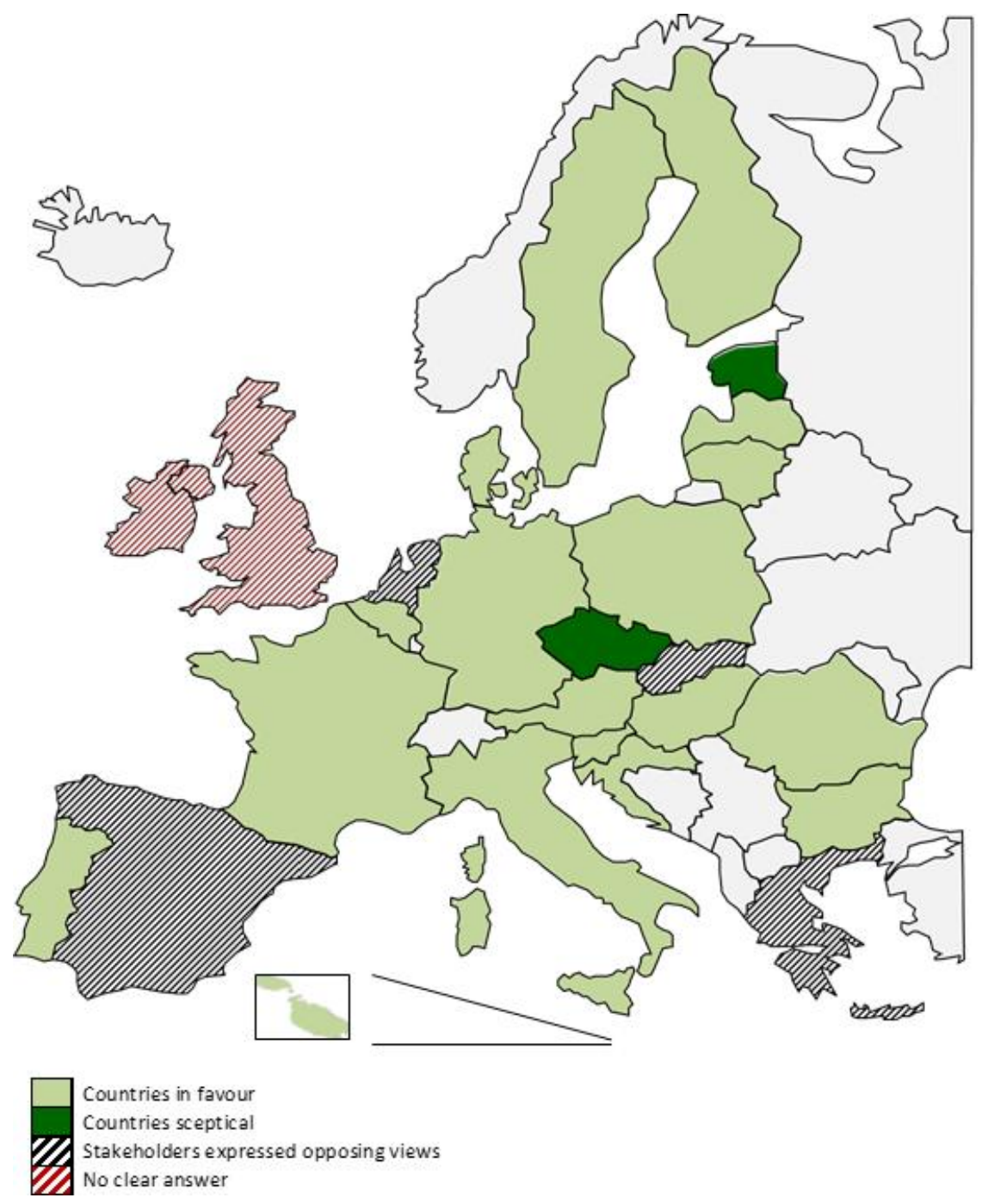

Fig. 5. Measuring the impact of health claims and symbols - EU overview

The main topics identified revolve around consumer understanding and trust in this type of information, vulnerable consumer groups (e.g. children) but also overall effectiveness of claims and symbols (do they lead to healthier choices and ultimately impact health?). A large proportion of debates mentioned concerns the legislative aspects, ranging from a general discussion about the Health Claims Regulation (application, wording, graphic implementation, process of approval (EFSA)) to specific aspects such as the status of certain types of claims (e.g. botanical claims), underlying nutrient profiles or criteria for the use of health symbols. 
Table 12. Research topics and suggested methods

\begin{tabular}{|c|c|c|c|}
\hline Area & Topics & Countries & Suggested methods \\
\hline \multirow[t]{4}{*}{$\begin{array}{l}\text { Consumer } \\
\text { research }\end{array}$} & $\begin{array}{l}\text { Awareness and } \\
\text { understanding of claims } \\
\text { and symbols (e.g. in the } \\
\text { context of the entire product } \\
\text { package) }\end{array}$ & $\begin{array}{l}\text { Belgium, Bulgaria, France, } \\
\text { Germany, Greece, Hungary } \\
\text { Netherlands, Poland, } \\
\text { Portugal, Romania, Sweden }\end{array}$ & $\begin{array}{l}\text { In-store surveys } \\
\text { On-line (panel) } \\
\text { surveys }\end{array}$ \\
\hline & $\begin{array}{l}\text { Perception and attitudes } \\
\text { (e.g. trust) }\end{array}$ & $\begin{array}{l}\text { Croatia, France, Germany, } \\
\text { Lithuania, Poland, Portugal, } \\
\text { Romania, Slovakia, UK }\end{array}$ & $\begin{array}{l}\text { In-store surveys } \\
\text { On-line (panel) } \\
\text { surveys }\end{array}$ \\
\hline & $\begin{array}{l}\text { Effectiveness (taking } \\
\text { context factors into } \\
\text { account) }\end{array}$ & $\begin{array}{l}\text { Belgium, Bulgaria, Croatia, } \\
\text { France, Germany, Hungary, } \\
\text { Italy, Lithuania, }\end{array}$ & $\begin{array}{l}\text { Purchase simulations } \\
\text { Actual (not self- } \\
\text { reported) data on use }\end{array}$ \\
\hline & $\begin{array}{ll}\text { - } & \text { Food choice } \\
\text { - } & \text { Purchase (e.g. } \\
& \text { willingness-to-pay) } \\
\text { - } & \text { Consumption }\end{array}$ & $\begin{array}{l}\text { Netherlands, Poland, } \\
\text { Portugal, Romania, } \\
\text { Slovakia, Slovenia, Spain, } \\
\text { Sweden, UK }\end{array}$ & $\begin{array}{l}\text { Focus groups } \\
\text { (qualitative) }\end{array}$ \\
\hline $\begin{array}{l}\text { Public } \\
\text { health }\end{array}$ & $\begin{array}{l}\text { Health outcomes / Impact } \\
\text { on (public) health } \\
\text { Health care spending }\end{array}$ & $\begin{array}{l}\text { Austria, Bulgaria, France, } \\
\text { Italy, Romania, Slovakia } \\
\text { Denmark }\end{array}$ & \\
\hline $\begin{array}{l}\text { Economic } \\
\text { aspects }\end{array}$ & $\begin{array}{l}\text { Prevalence of claims and } \\
\text { symbols }\end{array}$ & $\begin{array}{l}\text { Belgium, Croatia, Denmark, } \\
\text { Hungary, Portugal, } \\
\text { Romania, Slovenia }\end{array}$ & Product assortment \\
\hline & Effect on sales & $\begin{array}{l}\text { Poland, Romania, United } \\
\text { Kingdom }\end{array}$ & Sales data \\
\hline & Cost of implementation & Hungary, Italy, Romania & \\
\hline
\end{tabular}

Table 13. Arguments against measuring the impact of health claims and symbols

\begin{tabular}{|c|c|}
\hline Topics & Examples \\
\hline $\begin{array}{l}\text { Claims/symbols are } \\
\text { not seen as effective } \\
\text { (low public health } \\
\text { benefit) } \\
\text { Lack of know-how } \\
\text { (study design etc.) }\end{array}$ & $\begin{array}{l}\text { "Claims/symbols are not effective in fighting health issues (obesity etc.)" } \\
\text { (Austria, CO) } \\
\text { "Low expectations about beneficial public health effect through the use } \\
\text { of claims and symbols" (Netherlands, NFA) } \\
\text { "Complicated research" (Finland, NFA) } \\
\text { "How to measure it"' (Germany, NFA) } \\
\text { "The relationship between consumers, products and claims is complex. } \\
\text { Reading food labels, the nature of the consumer, their reason for } \\
\text { looking and what information they are looking for are all intrinsically } \\
\text { linked and therefore it is difficult to generalise about the impact on } \\
\text { consumer understanding of the claim itself." (United Kingdom, Food } \\
\text { Standards Agency) }\end{array}$ \\
\hline $\begin{array}{l}\text { Lack of responsible } \\
\text { authority } \\
\text { Lack of resources } \\
\text { Not seen as necessary }\end{array}$ & $\begin{array}{l}\text { "Who should measure it?" (Germany, NFA) } \\
\text { "Lack of resources" (Malta, NFA) } \\
\text { "Consumers already have positive attitude towards claims/symbols" } \\
\text { (Greece, IR) } \\
\text { "Sceptical whether impact studies deliver useful information" } \\
\text { (Netherlands, NFA) }\end{array}$ \\
\hline
\end{tabular}

\subsubsection{Stakeholder perception}

The topic of health claims and symbols was said to be discussed throughout most Member States, both on a public level (media reporting etc.) and within stakeholder groups (national authorities, industry and consumer representatives). While it is evident that this topic is of interest to most 
countries and stakeholders, the nature of the debate was reported to vary highly across the different stakeholders.

The nature of the public debate on health claims and symbols could be characterised by a variety of opinions expressed, both positive and negative towards the topic. National food authorities, representatives of the food industry and consumer organisations showed an interest in health claims and symbols in general. However, scepticism was expressed concerning specific articles of the Health Claims Regulation but also confusion with regards to the implementation (e.g. wording of the claims). Consumer organisations were mainly concerned with the potential of claims and symbols to mislead consumers and report confusion over meaning and effectiveness among shoppers. Overall, the topic was said to have received limited attention in the media, but where it has been covered, the public debate has focussed mainly on the application of the Regulation and the status of individual claims.

All interview summaries regarding stakeholder perceptions are presented in the Supplementary Material (Table 5).

Table 14. Themes of the public debate

\begin{tabular}{|c|c|}
\hline Topics & Countries \\
\hline Consumer understanding & Belgium, Denmark, Finland, Hungary, Ireland, \\
\hline Wording & Italy, Lithuania, Netherlands, Portugal, \\
\hline Risk of misleading & Romania, Slovenia, Sweden, UK \\
\hline Consumer acceptance and trust & Greece, Italy, Ireland, Netherlands, Portugal, \\
\hline Credibility of claim statements and symbols & Romania \\
\hline $\begin{array}{l}\text { Vulnerable consumer groups: Health claims } \\
\text { and children }\end{array}$ & Croatia, Hungary \\
\hline \multicolumn{2}{|l|}{ Effectiveness of claims and symbols } \\
\hline General importance & Hungary, Italy \\
\hline Impact on health (healthier choices) & Slovenia, Lithuania \\
\hline $\begin{array}{l}\text { Specific discussion on the keyhole symbol } \\
\text { - "Low carbohydrates high fat" movement in }\end{array}$ & Sweden, France \\
\hline \multicolumn{2}{|l|}{$\begin{array}{l}\text { - Development of a similar symbol in France } \\
\text { Legislation }\end{array}$} \\
\hline General discussion on Health Claims & Belgium, Czech Republic, Finland, Germany, \\
\hline Regulation and its implementation: How to apply & $\begin{array}{l}\text { Greece, Ireland, Italy, Netherlands, Poland, } \\
\text { Romania, Slovakia, Slovenia, Spain, Sweden, } \\
\text { UK }\end{array}$ \\
\hline - Wording & $\begin{array}{l}\text { Belgium, Czech Republic, Greece, Malta, } \\
\text { Slovenia, Sweden }\end{array}$ \\
\hline - Graphic implementation of symbols & France, Netherlands \\
\hline Process of approval (EFSA) & $\begin{array}{l}\text { Belgium, Czech Republic, Estonia, Finland, } \\
\text { Germany, Lithuania, Malta, Poland, Romania, } \\
\text { Spain }\end{array}$ \\
\hline Status of claims (e.g. botanical claims) & $\begin{array}{l}\text { Austria, Belgium, Croatia, Estonia, Finland, } \\
\text { Germany, Malta, Netherlands, Poland, Slovakia }\end{array}$ \\
\hline Nutrient profiles & Belgium, Denmark, Germany, Spain \\
\hline Criteria for the use of symbols & Portugal \\
\hline
\end{tabular}

\section{CONCLUSION}

Interviews with key stakeholders across Europe have shown that before the introduction of the EU Regulation (EC 1924/2006), health claims and symbols have been regulated or at least dealt with in a number of different ways. Only few national databases were said to have been in place, making a systematic monitoring of the use of claims and symbols difficult. Nevertheless, the stakeholders interviewed expressed a strong interest in measuring the impact of health claims and symbols, particularly research into the effects on consumer behaviour, public health and economic aspects. On national level, public debates were reported to have focussed on consumer understanding, acceptance and trust of claims, but also on the question of the 
effectiveness of such health-related information. Many questions posed by the interviewees revolved around the legislative aspects, i.e. how to apply the EU Regulation (No 1924/2006) with regards to wording issues, the evaluation process at the European Food Safety Authority (EFSA), the status of various claims and the nutrient profile modelling to be introduced in Europe.

\section{NOTE}

This work was carried out as part of the EUfunded project CLYMBOL ("Role of healthrelated claims and symbols in consumer behaviour", under Grant Agreement N 311693. This project has received funding from the European Union's Seventh Framework Programme for research, technological development and demonstration.

\section{COMPETING INTERESTS}

Authors have declared that no competing interests exist.

\section{REFERENCES}

1. Hieke S, Kuljanic N, Wills JM, Pravst I, Kaur A, Raats MM, Van Trijp HCM, Verbeke V, Grunert KG. The role of healthrelated claims and health-related symbols in consumer behaviour: Design and conceptual framework of the CLYMBOL project and initial results. Nutr Bulletin. 2015;40:66-72.

2. European Parliament \& Council of Europe. Regulation (EC) No 1924/2006 of the European Parliament and of the Council of 20 December 2006 on nutrition and health claims made on foods. Official Journal of the European Communities. 404.

3. Yamada K, Sato-Mito N, Nagata J, Umegaki K. Health claim evidence requirements in Japan. J Nutr. 2008;138: 1192S-8S.

4. Shimizu T. Newly established regulation in Japan: foods with health claims. Asia Pacific J Clin Nutr. 2002;11(2):S94-S6.

5. Yang $Y$. Scientific substantiation of functional food health claims in China. J Nutr. 2008;138:1199S-205S.

6. Tapsell LC. Evidence for health claims: A perspective from the Australia-New Zealand region. J Nutr. 2008;138:1206S9S.
7. Hasler CM. Health claims in the United States: An aid to the public or a source of confusion? J Nutr. 2008;138: 1216S-20S.

8. L'Abbe 'MR, Dumais L, Chao E, Junkins B. Health claims on foods in Canada. J Nutr. 2008;138:1221S-7S.

9. de Boer A, Bast A. International legislation on nutrition and health claims. Food Policy. 2015;55:61-70.

10. European Parliament \& Council of Europe. Directive 2000/13/EC of the European Parliament and of the Council of 20 March 2000 on the approximation of the laws of the Member States relating to the labelling, presentation and advertising of foodstuffs. Official Journal of the European Communities. 109/29.

11. Bech-Larsen T, Scholderer J. Functional foods in Europe: Consumer research, market experiences and regulatory aspects. Trends in Food Science \& Technology. 2007;18(4):231-4.

12. Asp NG, Bryngelsson S. Health claims in Europe: New legislation and PASSCLAIM for substantiation. The $\mathrm{J}$ of Nutr. 2008; 138(6):1210S-5S.

13. Hawkes C. Nutrition labels and health claims: The global regulatory environment. Report for the World Health Organization; 2004.

(Accessed 11 January 2016)

Available:http://apps.who.int/iris/bitstream/ 10665/4294/1/9241591714.pdf

14. Williams PG. Consumer understanding and use of health claims for foods. Nutr Rev. 2005;63(7):256-264.

15. Urala $\mathrm{N}$, Arvola $\mathrm{A}$, Lähteenmäki L. Strength of health-related claims and their perceived advantage. Int $\mathrm{J}$ of Food Science and Technology. 2003;38(7):815826.

16. Wahlqvist ML, Wattanapenpaiboon N. Can functional foods make a difference to disease prevention and control? Globalization, diets and noncommunicable diseases. Report for the World Health Organization; 2002.

(Accessed 11 January 2016)

Available:http://www.who.int/hpr/NPH/docs /globalization.diet.and. ncds.pdf

17. Lawrence M, Rayner M. Functional food and health claims: A public health policy perspective. Publ Health Nutr. 1998;1(2): 75-82. 


\section{APPENDIX}

For Cyprus, unofficially, information was obtained that health claims were not allowed on their own national products, before 2006. Imported products did bear some claims. However, this could not be confirmed via desk research. Due to other reasons, the national food authority for Cyprus declined to participate in these stakeholder interviews. Reason given was that this topic has not yet been discussed on national level. The persons contacted for the stakeholder groups 'consumer organisation' and 'industry representative' did not agree to an interview due to lack of involvement in the topic of health claims and symbols.

For Luxembourg, no response could be obtained from any of the stakeholders contacted.

(C) 2016 Hieke et al.; This is an Open Access article distributed under the terms of the Creative Commons Attribution License (http://creativecommons.org/licenses/by/4.0), which permits unrestricted use, distribution, and reproduction in any medium, provided the original work is properly cited. 